University of Windsor

Scholarship at UWindsor

1994

\title{
Labour's love lost: Observations on the historiography of class and ethnicity in the nineteenth Century
}

Peter Way

University of Windsor

Follow this and additional works at: https://scholar.uwindsor.ca/historypub

Part of the History Commons

\section{Recommended Citation}

Way, Peter. (1994). Labour's love lost: Observations on the historiography of class and ethnicity in the nineteenth Century. Journal of American Studies, 28 (1), 1-22.

https://scholar.uwindsor.ca/historypub/11

This Article is brought to you for free and open access by the Department of History at Scholarship at UWindsor. It has been accepted for inclusion in History Publications by an authorized administrator of Scholarship at UWindsor. For more information, please contact scholarship@uwindsor.ca. 


\section{CAMBRIDGE UNIVERSITY PRESS}

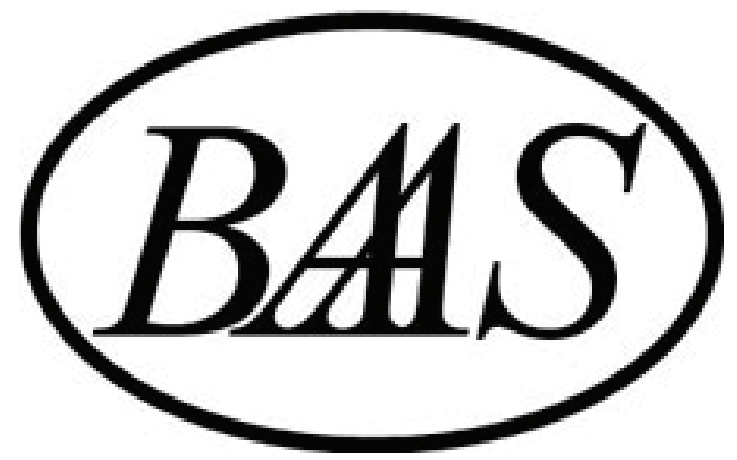

Labour's Love Lost: Observations on the Historiography of Class and Ethnicity in the Nineteenth Century

Author(s): Peter Way

Source: Journal of American Studies, Vol. 28, No. 1 (Apr., 1994), pp. 1-22

Published by: Cambridge University Press on behalf of the British Association for American Studies

Stable URL: http://www.jstor.org/stable/27555781

Accessed: 12/04/2013 12:14

Your use of the JSTOR archive indicates your acceptance of the Terms \& Conditions of Use, available at http://www.jstor.org/page/info/about/policies/terms.jsp

JSTOR is a not-for-profit service that helps scholars, researchers, and students discover, use, and build upon a wide range of content in a trusted digital archive. We use information technology and tools to increase productivity and facilitate new forms of scholarship. For more information about JSTOR, please contact support@jstor.org.

Cambridge University Press and British Association for American Studies are collaborating with JSTOR to digitize, preserve and extend access to Journal of American Studies. 


\title{
Labour's Love Lost: Observations on the Historiography of Class and Ethnicity in the Nineteenth Century
}

\author{
PETER WAY
}

In the fall of I 828, Irish labourers digging Pennsylvania's Mainline Canal at Clark's Ferry, near Harrisburg, rioted when their employers - the Mammoth Contracting Company of New York - fell behind in wage payments by as much as $\$ 400$ to skilled workers. ${ }^{1}$ The men soon returned to work, but in April the following year demanded a raise in wages from $8 \circ \varnothing$ to $\$$ I until they paid off debts to local storeowners accumulated over the winter. The contractors refused, but the next day a freshet partially washed out the dam on the Susquehanna and threatened the canal works. The labourers, many of whom had been unemployed for some time, refused to repair it until their wage request was met. Canallers from the surrounding area arrived to join the protest. The contractors attempted to erect a temporary dam with a few loyal hands, but were attacked by strikers with rocks and clubs. Likewise, skilled workers who remained aloof were forced to halt work and join the turnout. The river broke

Peter Way is Lecturer in American History, University of Sussex, Brighton BNi 9 QN, England. He would like to thank David Grimsted, Stephen Fender, Vivien Hart and other colleagues, for their comments on this paper.

\footnotetext{
1 This company was one of the first interstate canal-building firms and a company with a history of financial misdealings. In 1826 , a number of its managers were arrested in Pittsburgh for violation of contracts with the Ohio Canal Commissioners. And the following year, agents of the Mammoth Company working at Hunter's Falls on the Pennsylvania Mainline stopped paying their workers, who burned their employers' shanty and stable in revenge. [Pottsville, Pa.] Miner's Journal, is Aug. 1826; Bedford [Pa.] Gazette, s Oct. 1827 .
}

Journal of American Studies, 28 (1994), I, I-22 (C) 1994 Cambridge University Press 
through the dam causing $\$ 8-10,000$ damage, but still the workers persisted in their strike. Finally, the sheriff, posse and local militia were called out, and bloodshed was only averted by the intercession of Father Curran, a Catholic priest. After this, the workers went back to work, apparently without their raise. ${ }^{2}$

Such brief, violent outbreaks of worker unrest were common wherever hard manual labour was performed in nineteenth-century America. They have received little attention from historians, however, and usually are dismissed as trivial when discussed. This is not because they lack innate historical interest, but because they do not fit into the prevailing paradigms of labour and ethnic history. How are we to interpret the Clark's Ferry incident? Were these class-conscious workers warring with capital? Or were they immigrants united by a sense of their Irishness against bigoted, native-born employers? The difficulty of slotting the experience of these people hints at conceptual flaws within the existing literature.

The world of canal construction workers, like that of common labour in general (into which fell most immigrants, at least initially), was bounded by their economic need to perform hard physical toil. This labour was at wages set by an uncaring market, and unredeemed by the pleasure an artisan derived from applying his skill. The work was often irregular, dangerous and -in the case of public works - exposed to a variety of diseases, including typhus, malaria and cholera. Canallers lived in shanty towns, collections of rude huts built on the work site or at the margins of urban centres, which were temporary in nature and offered little opportunity for community building. ${ }^{3}$ Increasingly, the work was done by Irish immigrants who collected on canals through lack of options, where they met a regimen of hard work and trying living conditions. In the Clark's Ferry incident a group of workers with experience of financial problems with their employers exploited a natural disaster in an attempt to drive up wages and get out of debt. They apparently were not driven by any sense of ethnic or class grievance, just the will to exist, and were quite prepared to turn on fellow workers or skilled hands who would not

${ }^{2}$ [Baltimore] American and Commercial Advertiser, 9 April I 829; [Philadelphia] Poulson's American Daily Advertiser, 8 April 1829 . See also: William A. Sullivan, "A Decade of Labor Strife," Pennsylvania History, 17 (Jan. 1950), 32-33; Richard D. Borgeson, "Irish Canal Laborers in America; 181 7-1846," M.A. thesis, Pennsylvania State University, 1964, 48-51; Peter A. Wallner, "Politics and Public Works: A Study of the Pennsylvania Canal System, I825-I857," Ph.D. diss., Pennsylvania State University, I $973,76$.

${ }^{3}$ Peter Way, Common Labour: Workers and the Digging of North American Canals, $1780-1860$ (New York: Cambridge University Press, 1993). 
join the majority. The strikers remained firm in the face of local law and militia, but wilted when chastened by the Irish priest. Goals were limited, organization minimal, and community or cultural support not evident. These were people with little power taking advantage of what was at hand in a failed attempt to better their short-term conditions, not militant workers fired by artisan republicanism nor European ex-patriots driven by a strong sense of ethnic identity; that is, not the stuff of recent working-class and ethnic studies.

Labour and ethnic history are two main currents in the stream of social history that has dominated the profession for the past thirty years. A very diverse genre, it nonetheless shares a fundamental concern with the experience of dependent classes, those groups previously ignored by most historians. Here, the key concept has been human agency; in effect, to what degree were such groups able to construct their own world, and to what extent were they "made" by material forces beyond their control? In coming to grips with this question, social historians have naturally tended to concentrate on the realm of consciousness, albeit usually of a collective rather than an individual nature. By reconstructing such mentalités and situating them in the dynamic and autonomous cultures erected by labouring classes, these scholars sought to make a case for human agency, for the ideal over the material. The people are thus put front and centre of the historical process, where the aristos have always been. Such an approach, however appealing, does have its problems. Specifically, it has led to an idealization of past working lives and minimized the omnipotence of industrial capitalism in moulding the world according to its own precepts, a failing this examination of nineteenth-century labour and ethnic history seeks to demonstrate.

\section{II}

By far the most influential exponent of human agency was the British labour historian E. P. Thompson. Distancing himself from the materialism of the hard left, Thompson opted for a cultural model that accentuated the role of English labourers in the construction of their own class. Thompson's position has remained a continuing source of debate within British history for its undervaluing of material forces, political orientation, focus on skilled workers, and relative neglect of women, but mostly for its arguably overly-optimistic portrayal of working-class initiatives. According to Richard Price, by the early I 980 s the debate had resolved to a dispute between those who emphasized workers' opposition to and conflict with capitalists (the Thompsonian camp), and those who 
focused on labour's tendency to be co-opted and divided by the bourgeoisie (the opposition). ${ }^{4}$ By comparison, the concept of agency has gone virtually unchallenged by North American labour historians. Herbert Gutman, the main conduit for the importation of Thompson's ideas, was left largely unchallenged despite his relatively cruder handling of the material, and has spawned an entire generation of followers. The most important of these is Sean Wilentz with his championing of craft workers as the heart of the American working class and "artisan republicanism" as the fount of class consciousness. There have been those who have stood apart from this developing orthodoxy by continuing to admit the material constraints on human action, such as David Brody and David Montgomery, while a few like Lawrence McDonnell have made a determined effort to skewer the Thompson/Gutman culturalist interpretation. Still the worker hero stands tall. ${ }^{5}$

American labour history's fascination with agency has led to a form of idealism, with the concept of class consciousness at its heart. Crudely put: classes do not exist until they are aware of their existence, of their own special interests as a group opposed to all others, and act on this basis. This construction of class places on the historian the burden of proof; that is class must be demonstrated by concrete examples of class struggle. Within such phenomenalism, evidence of working-class culture and community is class consciousness made material, and thus verification of the existence of class in America. A concern with experience thus takes the place of the institutional perspective of the "old" labour history of the Commons school and the economism of business history, but only experience of a certain kind, for thought and action that gives rise to a conflicting reading of consciousness is problematic, unwelcomed and usually ignored or explained away. Here lies the root of the clash between

${ }^{4}$ E. P. Thompson, The Making of the English Working Class (Harmondsworth, England: Penguin, I 968); Perry Anderson, Arguments within English Marxism (London: Verso, 1980); Richard Price, Labour in British Society: An Interpretive History (London: Croom Helm, i 986), 4- .

${ }^{5}$ Herbert G. Gutman, Work, Culture, and Society in Industrializing America: Essays in American Working-Class History (New York: Vintage, 1977); Sean Wilentz, "Artisan Origins of the American Working Class," International Labor and Working Class History, 19 (Spring 198I), I-22 ; Sean Wilentz, Chants Democratic: New York City and the Rise of the American Working Class, 1788-1850 (New York: Oxford, 1984); David Brody, Steelworkers in America: The Nonunion Era (orig. ed. I960; New York: Harper \& Row, 1969); David Montgomery, The Fall of the House of Labor: The Workplace, the State, and American Labor Activism, 1865-1925 (New York: Cambridge University Press, 1987); Lawrence McDonnell, "'You Are Too Sentimental': Problems and Suggestions of a New Labor History," Journal of Social History, 17 (Summer 1984), 629-54. 
class and ethnicity (not to mention gender and race) as currently applied by their respective advocates: a contest over mental terrain.

Wishing to demonstrate class and convinced of its essentially cultural nature, labour historians of the nineteenth century have looked where they were liable to find it, among those workers with the most power, who were more likely to understand and resist capitalism's effects upon their lives: the skilled and organized. The hero of the piece is the artisan, who, drawing on a vibrant craft tradition dating back to the prerevolutionary era, resisted the incursions of industrial capitalism and sought to check the erosion of handicraft production. Though inevitably a failed effort, it was from the ashes of this struggle that the modern working class rose phoenix-like. Throughout the entire process according to such historians as Sean Wilentz, Alan Dawley and Bruce Laurie - the ideology of artisan republicanism with its main tenets of independence, equality, commonwealth and virtue acted as an intellectual framework with which to wage the class struggle. In effect, class consciousness in this period was republican in nature. "The history of class formation," asserted Wilentz, "is comprehensible only if it is understood in this broad ideological context." Historians have looked to sport, saloons and alcohol, firemen organizations, and religious, ethnic or fraternal societies as the vernacular expressions of this ideology, while parades, craft associations, unions and strike activity are seen as its more coherent manifestations. The litmus test of artisan republicanism, however, is political activity, so that the various fringe workingmen's parties and more militant working-class advocates such as Thomas Skidmore move centre stage. A working-class culture with relative integrity and autonomy is thus constructed from these disparate pieces, republicanism the glue holding the whole together. ${ }^{6}$

Labour historians have made a compelling case for class experience in America. The changing conditions of work, the threads that make up labourers' lives, are untangled, while the machinery that drove the workers is set in motion, tinkered with, oiled. The craftsman historian lovingly holds the finished product, the colourful fabric of working-class culture, up to the light for inspection. Yet this tapestry of toil is flawed.

\footnotetext{
${ }^{6}$ Sean Wilentz, Chants Democratic, i4; Alan Dawley, Class and Community: The Industrial Revolution in Lynn (Cambridge, Mass.: Harvard University Press, 1976); Bruce Laurie, Artisan into Workers: Labor in Nineteenth-Century America (New York: Noonday Books, 1989). See also: Susan E. Hirsch, Roots of the American Working Class: The Industrialization of Crafts in Newark, I800-1860 (USA: University of Pennsylvania Press, 1978), and Jonathan Prude, The Coming of Industrial Order: Town and Factory in Rural Massachusetts, I810-1880 (New York: Cambridge University Press, I983).
} 
First and foremost, by concentrating on artisan/skilled workers this brand of labour history has told only part of the story. Second, it idealizes the preindustrial past relative to the industrial future, and portrays the breakdown of "traditional" society as a human tragedy, without adequately examining this earlier era. Finally, labour history's idealism has exposed it to attack from the centre and right, and led it into a debate over the existence or non-existence of class consciousness that has distracted it from the central issue, the nature and construction of class.

By concentrating on the organized, specifically artisans and skilled factory workers, working-class historians have ignored other areas of the labour experience. The emerging orthodoxy provides a white, male, skilled and unionized vision of labour history. ${ }^{7}$ The usual periodization perpetuates this interpretation; most studies focus on the late-I gth and early-2oth centuries when labour was most organized and militant. Labour history is threatening stagnation by going over the same ground, finding some new craft or community, and unravelling its story against the background of developing monopoly capitalism and vigorous class conflict. It is becoming a neo-Commons school, measuring the scale of class experience, albeit with a cultural and political rather than institutional rule. Despite its pretensions to be "working-class" history, it is more a new breed of "labour" history, except its focuses on labour movements as opposed to Commons' unions. The literature's keen interest in working-class politics, and love for lost causes like the Knights of St. Crispins and Knights of Labour underline this historiographical bent. For example, Leon Fink, in one of the spate of recent efforts to get labour history back on the tracks, wrote that working-class movements of the period I 830-90 were based on "organization of skilled workers, artisanal values of production, and republican (or democratic-nationalist) political

7 It is an interpretation that has even been uncomfortably grafted on the history of women workers. For example, both Thomas Dublin's wish to see Lowell's women weavers as republican workers and Faye Dudden's treatment of domestic service as proletarianization from a community of "help" to the class lines of servant and mistress, with their shared themes of declension from a more humane and equal past, ring falsely alongside their handling of their subjects as women whose experience with gender exploitation transcends this model. Christine Stansell and Mary Blewett come closer to the mark in their handling of gender and class. Thomas Dublin, Women at Work: The Transformation of Work and Community in Lowell Massachusetts, 1826-1860 (New York: Columbia University Press, 1979); Faye E. Dudden, Serving Women: Household Service in Nineteenth-Century America (Middletown, Connecticut: Wesleyan University Press, 1983); Christine Stansell, City of Women: Sex and Class in New York, 1789-1860 (Chicago: University of Illinois Press, I987); Mary Blewett, Men, Women, and Work: Class, Gender, and Protest in the New England Shoe Industry, 1780-1910 (Chicago: University of Illinois Press, 1988). 
ideals." ${ }^{8}$ However true for the subjects of which he speaks, it is dubious that this characterization applies to the majority of workers during that era. Certainly, the experience of common labourers would be incomprehensible within such a framework.

Over twenty years ago, David Montgomery wrote an article that was refreshing in its examination of unskilled workers, such as common day labourers, seamen, longshoremen, carters and workers on transportation projects. His leads have only recently been picked up. ${ }^{9}$ Manual labourers were the primary fuel for industrial capitalism for its first century and more in North America. Uprooted from the land and converted into wage labour they were truly alienated, with no socially-accepted skills to ward off the embrace of the market. They were drawn from a spectrum of sources - men, women and children, British, Irish, German, eastern and southern Europeans, African American and Chinese - which made for a segmented workforce. This bred differences that opened the door to intraclass conflict, while capital took advantage of gender, ethnicity and race, not to mention class, to enhance exploitation. The rise of industrial capitalism was a more harrowing experience for common labourers than for the craftsmen that dominate labour history. They were more socially and economically marginalized, highly transient with ever-dissolving community ties, and did not necessarily have a coherent political ideology like republicanism with which to understand or resist their condition. Together they constituted a classic proletariat. $^{10}$

Such workers were not class conscious, at least not in any easily definable terms. The segmented nature of the workforce and the pull of old

${ }^{8}$ Leon Fink, "Looking Backward: Reflections on Workers' Culture and Certain Conceptual Dimensions within Labor History," in Perspectives on American Labor History: The Problem of Synthesis, ed. J. Carroll Moody and Alice Kessler-Harris (Dekalb, Illinois: Northern Illinois University Press, 1989), 8.

9 David Montgomery, "The Working Classes of the Pre-Industrial City, 1780-1830," Labor History, 9 (Winter 1968), 3-22. See, for example: Walter Licht, Working for the Railroad: The Organization of Work in the Nineteenth Century (Princeton: Princeton University Press, 1983); Shelton Stromquist, A Generation of Boomers: The Pattern of Railroad Labor Conflict in Nineteenth-Century America (Chicago: University of Illinois Press, 1987); James Barrett, Work and Community in the Jungle: Chicago's Packinghouse Workers (Chicago: University of Illinois Press, 1987); Brian C. Mitchell, The Paddy Camps: The Irish of Lowell I821-6I (Chicago: University of Illinois Press, I988); David Emmons, The Butte Irish: Class and Ethnicity in an American Mining Town (Chicago: University of Illinois Press, 1989).

10 I make this argument at greater length in "Evil Humours and Ardent Spirits: The Rough Culture of Canal Construction Labourers," Journal of American History, 79 (March 1993), I 397-1428. 
allegiances prevented the emergence of a broad-based sense of class. They as often fought with each other as with their employers. At the same time, their experiences were entirely shaped by class forces, and they periodically pieced together the fragments of their lives to act upon their position within the developing capitalist world order, and take collective steps to resist the tide. These class epiphanies were usually shortlived, as the centripetal forces of their existence threw them back into their ghettoes, their squabblings and their rounds of work and intoxication. The different make-up of the workforce and the lower reaches of society to which their occupation consigned them meant that the common labourers' tale differed materially from that of artisans/workers, yet it is at least as revealing of the broad labour experience in the I9th century, the organized and skilled never amounting to more than a minority. ${ }^{11}$

On the second point, the Manichaean world view of labour history, the artisan-to-worker model is erected upon a conceptualization of class formation that implies a false dichotomy between a better, more personal past for the labouring classes, and a hostile future in which workers are faceless cogs in the machinery. The independent artisan within labour history constitutes the urban equivalent of the Jeffersonian yeoman farmer, both being guided by virtue and acting as the repository of all that was good about America. Such an idealization of traditional craft production helps to set up the horrors of industrialization. While roughly accepting the latter half of the equation, one must be wary of sentimentalizing what went before. The movement of non-artisans into wage work was not necessarily an unalloyed experience of decline and loss of power. Many never had power to begin with. A slave or indentured servant who was freed, or an Irish peasant forced away from a deprived lifestyle on the land could see proletarianization as a distinct movement upwards. A farmer always at the mercy of the weather was not in complete control, and could envy the freedom offered by cash wages. Even a craft journeyman might perceive the advantages in moving out of his boss's house into a home of his own, and of being given greater choice for whom he would work. ${ }^{12}$ Tradition can be as much a burden from the past as a

11 See Andrea Graziosi, "Common Laborers, Unskilled Workers: i 880-1915," Labor History, 22 (Fall I 98 I), 5 I 2-44; Montgomery, Fall of the House of Labor, chapter 2; Peter Way, "Shovel and Shamrock: Irish Workers and Labor Violence in the Digging of the Chesapeake and Ohio Canal," Labor History, 30 (Fall 1989), 489-517; Way, "Evil Humours and Ardent Spirits."

12 James A. Henretta, "Families and Farms: Mentalité in Pre-Industrial America," William and Mary Quarterly v. 35 (Jan. 1978), 3-32; Gary Nash, The Urban Crucible: The Northern Seaports and the Origins of the American Revolution (Cambridge, Mass. : Harvard University 
refuge from the future. The experience of common labourers, who had no real golden age to hearken to, underlines this ambivalence.

This having been said, it must be made clear that a fundamental shift occurred as a result of the rise of industrial capitalism, and, for free individuals at least, this resulted in a definite loss of control. Threat of an early frost and drought are one thing for a farmer with a grasp on the land and control over subsistence. But a wage worker was dependent on his or her labour for a living yet had little control over its value or use, while being driven by the same natural forces that harassed farmers. This meant having less say in their day-to-day existence, the hours, wages, conditions or even possibility of work. One need not paint the past in golden hues to make this point, however.

The third problem with the literature is its idealism. Labour historians have constructed a Cartesian class model in which to think is to be, and where examples of independent thought or action are sought out and elevated to an articulation of class. This is not to say that they are insensitive to material forces, which, in fact, shape their entire model. But after outlining objective conditions, historians tend to leave them in the background and to focus on evidence of agency. They parachute into episodes of kinetic action of a class character, or of collective social experience. This tactic truncates and personalizes the historical process, which has the advantage of giving a human face to objective conditions, but implies more human agency than really exists. In effect, it smooths out the material and structural restraints on positive social action. As a result, there has been a tendency to exaggerate the cohesiveness of labour's experience, ignore the negative social costs of designated cultural icons such as drinking and brawling, and inflate the experiential and cognitive over the material, a lightfingered handling of people caught in the steel grip of a harsh working life. The result is an almost hagiographical treatment of labour that abstracts it from the dirt and grime of work.

Republicanism is central to this idealism, but, as Daniel T. Rogers has recently pointed out, it is a very slippery concept. Rooted in the intellectual history of Pocock and consensus writings of Louis Hartz,

Press, 1979); Sharon Salinger, "To Serve Well and Faithfully": Labor and Indentured Servants in Pennsylvania, 1682-1800, (New York: Cambridge University Press, 1987); Stephen Innes, ed., Work and Labor in Early America (Chapel Hill: University of North Carolina Press, 1988); Marcus Rediker, Between the Devil and the Deep Blue Sea: Merchant Seamen, Pirates, and the Anglo-American Maritime World, 1700-1750 (Cambridge: Cambridge University Press, 1987). 
Bernard Bailyn and Gordon Woods, republicanism has experienced surprising success within the historical profession for the past two decades. The main worrying point is that it has proved sufficiently malleable to find homes across the political spectrum. Anything so plastic suggests a lack of substance. The main feature of republicanism making it so attractive to conservative, liberal and leftist alike is its ability to engage the world of ideas in both political and social terms. This has perfectly suited it to the crucial debate over the nature of American society in the eighteenth and early nineteenth centuries, particularly the timing of the shift from a traditional republican society to a liberal-capitalist one. Republicanism could be applied widely and seemed to solve a lot of unanswered questions, but in many ways heralded a return or at least reprise of many ideas paramount in the 1950s during the heyday of consensus history, particularly the question of national character. ${ }^{13}$ This in itself should cause labour historians to pause and reflect, while the intellectual bent of the concept proves problematic for theorists who should be fundamentally concerned with material forces.

This idealism carried to the extreme has led to the current fashion of looking to discourse as the fount of historical process. Plundering poststructuralist language theory, historians such as Gareth Stedman Jones and Joan Scott have argued that it is the perception and articulation of events that give them their meaning. Treating the mind as the crucible of past action yields a potentially dangerous relativism, however, making workers lords of their own worlds rather than slaves to their material needs. As Joyce Appleby has argued in a liberal critique, such treatments abstract texts from their history and authors, in effect strip them of a contextual understanding. Textual analysis is helpful in outlining how people saw themselves and society, and provides another helpful source for the study of oppressed groups, but it is a pretty rarefied form of inquiry that should not pretend to utter comprehension of historical process. Less time should be spent deconstructing texts and more in reconstructing history. ${ }^{14}$

13 Daniel T. Rogers, "Republicanism: The Career of a Concept," Journal of American History, 79 (June 1992), I I-38.

14 Gareth Stedman Jones, Languages of Class: Studies in English Working Class History, 1832-1982 (London: Cambridge University Press, 1983); Joan W. Scott, "On Language, Gender, and Working-Class History," with responses by Bryan D. Palmer, Christine Stansell, and Anson Rabinbach, International Labor and Working-Class History, 31 (Spring 1987), I-36; Joyce Appleby, "One Good Turn Deserves Another: Moving beyond the Linguistic; A Response to David Harlan," American Historical Review, 94 (Dec. 1989), 1326-32; Bryan D. Palmer, Descent Into Discourse: The Reification of Language and the Writing of Social History (Philadelphia: Temple University Press, 1990). 
This idealization has proven the achilles heel of labour history. A neoconsensus reaction has set in that questions working-class consciousness in America and asserts the dominance of capitalist values. "What about immigrants, the unskilled, women workers and blacks?," critics ask, the people who were at the bottom of the working class, rarely organized and with but a dim perception of class, at least in the political sense. Any incident in which workers did not seemingly act in their own interests, or times when ethnicity, race or gender ostensibly overrode class, are seized upon as evidence of a lack of class consciousness, and, by implication, class. Critics point to the unskilled and unorganized, and trundle out the fact that most American workers have never been unionized. They ask the spurious question that will not die: why did America not produce an enduring socialist tradition such as in Europe? Their answer is that workers were bought off by prosperity and deluded by capitalist hegemony with its ideals of property, individualism and competition, or were pulled by ethnic and religious allegiances far more strongly than any sense of collective class status. ${ }^{15}$

These questions point to real problems within the literature, although American "Exceptionalists" have used them to mock the left with its seeming dwarfism compared to its European comrades. At its worst, when put forward by historians of the right such as John Diggins, this critique of labour history is an elitist interpretation that is dismissive of workers and their experiences. At its best, the neo-consensus viewpoint posits a liberal-pluralist interpretation of the past, where a plethora of groups and consciousnesses jumble together in the great American social marketplace, within which class is but another variable. ${ }^{16}$ Both posit a

15 Richard Oestreicher has reviewed the on-going debate about the importance of class in workers' lives, which usually pivots on the issue of working-class politics and the primacy of ethnic affiliations. He admits that in late-nineteenth century Detroit, "immigrant workers and their children did function simultaneously in competing cultural systems appealing to contradictory loyalties," and, as a result, voted for mainstream parties not radical alternatives, but argues that this fact might be more indicative of the closed political system than their parochialism or innate conservatism. "Urban Working-Class Political Behavior and Theories of American Electoral Politics," Journal of American History, 74 (Mar. 1988), I 268, I 275. See also his Solidarity and Fragmentation: Working People and Class Consciousness in Detroit, 1875-1900 (Champaign: University of Illinois Press, 1986).

16 See, for example, John P. Diggins, "The Misuses of Gramsci," Journal of American History, 75 (June 1988), I4I-45. David A. Gerber's recent study on Buffalo conveys what I would consider a liberal neo-consensus viewpoint. He claims to study "social pluralism'... a form of society characterized by public competition among large, complex groups composed of overlapping social solidarities." Of these, he considers social class and ethnicity the most important, but treats them as one and the same. The 


\section{2 Peter $W$ ay}

view of America as unique, set apart from Europe either by a common faith in liberal capitalism (as in the former variant) or an ultimately consensual mixing of diverse sociocultural groups (as in the latter), in which class is not the fundamental dynamic and conflict, while present, is neither substantial nor overly threatening. Despite ideological differences, working-class history nonetheless shares with these approaches a basic theoretical concern with consciousness. Thus it has been labour historians' ambiguous handling of class that has spawned this contrary position. They have, in effect, been hoisted upon their petard, and as a result have permitted the discussion to be decoyed into an intellectual cul de sac. It is not that the discussion over class consciousness and capitalism's cultural hegemony is not interesting or vital to the field, but that it is only one of a number of very important questions that have been shunted aside by its one-track logic.

This debate misses the crucial point, the nature of class, which at its roots is economic and structural rather than ideological and cultural. By focusing on consciousness (or its absence) both positions make the whole burden of class rest on the shoulders of workers, assuming that they have control over their fate: they choose to be aspiring members of the bourgeoisie rather than socialists, or, conversely, militants not militarists. But class consciousness is not the central issue. It fluctuated over time, coming and going with changes in workers' objective conditions. As long as debate hinges on demonstrating its persistence or non-existence, consensus historians can dismiss class in America as a pipedream of socialists. There is no question that there is class in America; to say otherwise is a delusion. Whether workers have bought into the American system is but one component of the issue of class. American workers, at least in the twentieth century, have been less militant than their European counterparts. While this may indicate only fleeting class consciousness, it is not because there is no working class or a weak one at best. What is important is how they got to this point of accommodation. The fact that the workers participate freely in the capitalist system and consciously accept its validity is not proof of a fundamental unity of interest, or of

cumulative effect of these competing tendencies is that the American system is able "to defuse and absorb conflict and to integrate new and foreign groups." The Making of an American Pluralism: Buffalo, New York, I825-I860 (Urbana: University of Illinois Press, 1989), xi-xii. There is a certain conceptual imprecision evident here, a mixing of apples and oranges that indicates a wish to treat everything evenhandedly and to have them play on a level field, which is a theoretical hallmark of the pluralist interpretation. 
the inconsequentiality of class. Conformity to the capitalist hegemony on one level is consensual, but on a more important level is the result of class struggle in which the mentalité of workers has been misappropriated or manipulated to work against their class interests. So consensus historians were correct in identifying a shared faith in liberal capitalism but wrong in scotching from history the essential conflict that enabled the imposition of this view on the masses, a mistake being replicated by neo-consensus liberals and conservatives, as well as some on the left.

Labour history is in danger of losing its way. If not in crisis, it is confused as to its future directions, a fact made clear by a series of introspective articles calling for consolidation and synthesis. ${ }^{17}$ While these are positive goals, they should not absorb all or even a majority of our energies. We should not let opponents define the terrain. What is needed is diversification not simplification, increased spadework in a broader field. The debate should be expanded beyond idealism - beyond workingclass thought and action - to include the actual process of capital and class formation. Greater attention must be paid to how the nature and organization of production altered, and what effect this had on social relations between the developing classes. More research needs to be done on the rural roots of capitalism (which entail stretching the normal periodization back into the $17^{\text {th }}$ and 18 th centuries), and on the exact relationship between slavery and capitalism, all of which are beginning to receive the scrutiny that is their due. Historians must look beyond the labour aristocracy and study the broader working class: women, children, blacks, ethnic groups, the unskilled and unorganized. People from very different backgrounds were broken down to wage work, becoming members of a class divided by race, gender, ethnicity and skill. They were a fragmented workforce with little opportunity to develop a sense of solidarity, and little power to effect beneficial change. They lived in a nation wealthy enough to satisfy the needs of most people while many prospered. The bill was in part paid by wealth extracted from slaves at home, as well as peasants and workers elsewhere in the world. But North American workers were still members of a labouring class kept from power by an exploiting class. The fact that workers may have accepted their relative prosperity in a way that tempered radicalism, was, rather

17 David Brody, "The Old Labor History and the New: A Review Essay," Labor History, 20 (Winter I979), I I I-26; David Montgomery, "To Study the People: The American Working Class," Labor History, 2 I (Fall 1980), 485-512 ; Leon Fink et al., "A Round Table: Historical Pessimism and Hegemony," Journal of American History, 75 (June I 988), I I -6I ; Moody and Kessler-Harris, eds., Perspectives on American Labor History. 
than proof of the absence of class, its greatest indicator. In effect, capitalism won, and workers were only dimly aware of their class: the perfect conditions for capitalist production.

III

Ethnic historians, like their labour colleagues, have a similar concern with the concepts of agency, consciousness and community. In this context, the question revolves around whether emigrants were pushed or pulled, whether they were forced by historical forces to leave their homelands or chose to move as a result of a rational evaluation of their present and future condition; and once in the New World, whether they were broken down and assimilated, or were able to construct healthy ethnic communities that formed the basis for integration into pluralist society.

Emigration was traditionally seen as forced, a combination of poverty and overpopulation making the poor leave their home country. As William Forbes Adams wrote of Ireland: "The compelling motive behind the great shift of population, the most momentous in the first half of the nineteenth century, was distress." While the attraction of America played a part, "it is in the state of Ireland that we must look first for the causes of emigration." The pushed case was made famous by Oscar Handlin with his "uprooted" model, which dominated the field from the ri940s to ig6os. Handlin and his followers emphasized cultural breakdown: peasants were uprooted from their homeland by economic hardship or ethnic-religious persecution, forced to emigrate and make an arduous journey across the ocean, to land friendless and penniless on foreign shores where they were defrauded by conmen and exploited by employers. Most gathered in urban ghettoes to be victimized by unemployment, poverty, disease, native prejudice and violence. Gradually they were absorbed by American society in a painful process of assimilation. As Handlin warned in the introduction to The Uprooted, "I shall touch upon broken homes, interruptions of a familiar life, separation from known surroundings, the becoming of a foreigner and ceasing to belong...t the history of immigration is a history of alienation and its consequences." Handlin meant alienation in a social/psychological sense primarily, but the term could be applied as aptly economically, for Handlin's immigrants were transformed from peasants to proletarians, that is alienated from the means of production through their migration. ${ }^{18}$

18 William Forbes Adams, Ireland and Irish Emigration to the New World from I8Is to the Famine (orig. ed. 1932; Baltimore: Genealogical Publishing, 1980), 2; Oscar Handlin, 
Rejecting Handlin's uprooted interpretation, recent studies have opted for a "transplantation" model which tends to emphasize the pull of the New World and immigrants' agency in making the move. ${ }^{19}$ It was not the poorest and most backward who left first but those with some sense of the outside world; in effect, emigration was conditioned by cultural factors. Moreover, emigrants to North America were not the impoverished, starving masses of the traditional view but people of middling status, a point that implies some choice in migrating. Others have argued that better economic conditions in North America meant emigrants were pulled by opportunities in the New World as often as not. Finally, not all joined the urban proletariat, as many found their way into rural areas, and, presumably, independent status. ${ }^{20}$

As well as portraying migration as a matter of choice as much as of force, this school argues that it was a move made coherent by shared ethnic culture. Social organizations and mores provided a context of continuity that allowed immigrants to adjust to the new environment. In particular, religion, the family, fraternal societies, education and political participation are seen as the bulwarks of ethnic American culture. Individuals possessed a strong ethnic consciousness that guided them through the thicket of an oft-hostile New World, giving them a conceptual framework to absorb and order their experiences as workers

The Uprooted (New York: Grosset \& Dunlap, I951), 4. See also: Handlin, Boston's Immigrants: A Study in Acculturation (orig. ed. I94I; New York: Atheneum, 1970); Robert Ernst, Emigrant Life in New York City, I825-1863 (New York: King's Crown Press, 1949); Earl F. Niehaus, The Irish in New Orleans, I800-I860 (Baton Rouge: Louisiana State University Press, 1965); Kenneth Duncan, "Irish Famine Immigration and the Social Structure of Canada West," in Studies in Canadian Social History, ed. Michael Horn and Ronald Sabourin (Toronto: McClelland and Stewart, 1974), 1 40-63.

19 For examples of the transplanted school, see: Dennis Clark, The Irish in Philadelphia: Ten Generations of Urban Experience (Philadelphia: Temple University Press, 1973); Kathleen Neils Conzen, Immigrant Milwaukee, 1836-1860: Accommodation and Community in a Frontier City (Cambridge, Mass.: Harvard University Press, 1976); Hasia R. Diner, Erin's Daughters in America: Irish Immigrant Women in the Nineteenth Century (Baltimore: John Hopkins University Press, 1983); John Bodnar, The Transplanted: A History of Immigrants in Urban America (Bloomington: Indiana University Press, 1985); Dennis Clark, Hibernia America: The Irish and Regional Cultures (Westport, Connecticut: Greenwood Press, 1986); Bruce S. Elliott Irish Migrants in the Canadas: A New Approach (Kingston and Montreal: McGill-Queen's University Press, i 988 ).

20 Donald $\mathrm{H}$. Akenson, in particular, has waged a relentless and quixotic battle against Handlin. See: The Irish in Ontario: A Study in Rural History (Kingston and Montreal: McGill-Queen's University Press, 1984); Being Had: Historians, Evidence, and the Irish in North America (Port Credit, Ontario: P. D. Meany Publishers, 1985); and Small Differences: Irish Catbolics and Irish Protestants, 1815-1922: An International Perspective (Kingston and Montreal: McGill-Queen's University Press, 1988). 
and citizens. Ethnicity and immigrant community in the transplantation model become the equivalent of labour history's class consciousness and working-class culture; at root, it is equally idealistic, though it is not as theoretically explicit.

Handlin's hapless peasant to proletarian framework thus has been largely rejected by current ethnic studies. ${ }^{21}$ The key departure by the transplanters is the degree to which they feel volition played a part in the process. In the place of the uprooted depiction they have substituted a scenario within which rational individuals weigh the pros and cons, and make the choice to emigrate. As John Bodnar argued, peoples' decision to stay or go, "conditioned by their social station, family status, and ideological orientation, becomes a variable itself helping to structure not only their own life path but even somewhat the all-embracing economic system. Ordinary individuals are rescued from the status of victims; they are not simply manipulated by leaders, their class standing, or their culture, but active participants in the historical drama whose outcome is anything but predictable." ${ }^{22}$ Migrants' active role persisted in the New World, where their strong sense of the past and membership in vital ethnic communities made immigration a difficult but ultimately successful exercise in ethnic cross-pollination. As individuals and groups, they were able to carve out a place for themselves in North American society. In effect, this interpretation has reformulated the case for the American pluralistic ideal, with its view of society as combative but accommodating and ultimately unified. Thirty years of social history has thus paradoxically arrived back at its consensus antithesis, although Canada's ideal of the "cultural mosaic" has been substituted for America's "melting pot." This essentially optimistic view is flawed because it tends to exaggerate people's control over immigration and adaptation, and does not define adequately its central concept of ethnicity, leading to a historically flat portrayal of the ethnic experience.

On the first point, the question of choice in emigration, a distinction must be made between the contemporary world of the individual and its

${ }^{21}$ Kerby Miller stands outside this growing consensus. His extensive examination of the Irish background to the most massive of migrations makes him painfully aware of the dwindling opportunity available to most Irish people. To a certain extent, then, he recapitulates the Irish Catholic peasant to disadvantaged North American model. At the same time, he is careful to outline a culture of emigration that led many, particularly Ulster Protestants, to view America as a place where one's position could be bettered. $\mathrm{He}$ is thus a combination of the push and pull interpretations, and consequently the most balanced of recent immigration studies. Miller, Emigrants and Exiles: Ireland and the Irish Exodus to North America (New York: Oxford University Press, 1985).

${ }^{22}$ Bodnar, The Transplanted, xx. 
historical dimension. People did make decisions that influenced their lives, but these were choices that history had strongly influenced. Those with greater exposure to the modern world were more likely to emigrate, and to do so in terms of how it might profit them as the transplanters would have it. Yet cultural and economic willingness to relocate was the product of historical process and a measure of a region's integration into the market. It does not really contradict the position that emigration was forced. Social and economic developments worsened conditions to the point that many had little option but to leave, and those inducements that led them on gained their persuasive power by comparison to the depression of existence at home. In the short term then, people did exert some control over what their course would be - whether, when, where, or how they would emigrate - and such decisions were of obvious importance to them. But seen over time, the choice they made was between Scylla and Charybdis, twin rocks thrust up by the tectonic forces of history. The great migrations of the sixteenth through twentieth centuries were prompted by the rise of capitalism, and entailed a redistribution of the world's human capital. While they were composed of millions of individual atoms all on their own peculiar course, these had little say over the forces that propelled their movements.

Once in North America, ethnic historians' desire to demonstrate continuity and the creation of dynamic immigrant communities has led to an overly-optimistic portrayal of culture that is not unlike that of labour historians. It exaggerates internal coherence and minimizes divisions of class, gender and religion, only in this case the cultural paragon is not the class-conscious worker but an immigrant with a strong ethnic identity. The reality was much less positive. Some groups were more successful than others in either carving out their own place or assimilating within North American culture, but whether they prospered or not is not the point in the broader historical context, and it is clear that most did not for some time. Those that did, did so on the terms of the host society; that is, as individuals in a competitive, capitalist system rife with prejudice. This usually required leaving much of their past behind. For those less fortunate, their ethnicity was used as an excuse to exploit them as among the least fortunate members of a class. And most immigrants were initially situated at the bottom of the class structure. Ethnicity was thus not an unalloyed benefit, and the experience of most ethnic groups was hardly a constructive one. The strength they demonstrated was more a result of their haphazardly piecing back together a culture that immigration had irreparably shattered. 
The second weakness in the current literature is its failure adequately to define ethnicity. By not specifying what exactly is meant by the term, it loses much of its effectiveness as a historical concept. Its imprecision walls off the past, and enables other distinctions - class, gender, religion - to be bricked over.

Ethnic studies have been strongly influenced by the Chicago school of sociology that emerged at the turn of this century. These early social scientists performed community studies with a particular focus on immigrant groups and their assimilation within American society, as indicated by residential, occupational and wealth patterns, among other variables. ${ }^{23}$ Ethnicity was a sociological construct, a measureable object, to these scholars. By reifying what is immaterial, sociologists made ethnicity a static and essentially descriptive determinant, implicitly seen as something that remained constant over time and from person to person. This sociological reading of the concept has strongly influenced the historical literature, especially since the advent of quantitative history with its need of fixed categories.

For all its apparent certitude, such a rendering of ethnicity masks its essential ambiguity. When attempting to specify its components, historians have handled it warily, being fearful of perpetuating stereotypes. Yet, when push comes to shove, they have tended to use the concept as if it meant nationality, something assumed and timeless; in fact, ethnicity becomes an unsophisticated model of national culture. This treatment is problematic for a number of reasons, beginning with its ahistorical nature. Ethnicity is not a trait handed on from generation to generation. To be German, Irish or English does not mean the same thing in one period that it does in another. The lives of Irish Famine immigrants, for example, differed both from earlier and later arrivals. Rather, ethnicity rests on historically significant cultural patterns experienced by a society as a whole. These experiences can encompass a variety of forms - religious, regional, political, gendered - but are rooted in a historical process which gives them shape.

The second problem with the concept of ethnicity as currently applied is its tendency to flatten experience according to a single variable. Nativity is seen as the determining force in an immigrant's life, and ethnic consciousness as moulder of experience. But was the world of a wealthy Irish-American merchant in Baltimore the same as that of a recentlyarrived Irish navvy on the nearby Baltimore \& Ohio Railroad? And did the experiences of a domestic servant necessarily coincide with that of her

\footnotetext{
${ }^{23}$ See, for example, Robert Ezra Park, Race and Culture (New York, Free Press, 1950).
} 
male compatriots who joined the Ancient Order of Hibernians? The American literature also crudely bridges the religious divide, for example treating Irish implicitly as Irish Catholic. The majority of Irish-American were undoubtedly Catholic, but to subsume Protestants within their experiential hegemony is ridiculous given Irish history, and points to the problems of using ethnicity as an all-inclusive concept. ${ }^{24}$ Finally, by focusing on nativity, ethnicity becomes in part a teleological concept, imposing modern national order on what was not necessarily so organized. One need only think of fragmented "Germany" or "Italy" to understand that cultural factors other than the ethno-national intruded.

While not underestimating the power of ethnic affiliation, it must be clear that class, gender, regionalism and religion, among other factors, made for a variety of experiences, a plethora of consciousnesses. The unifying factor was the material restraints placed on the individual's physical and mental being. Ironically, it is the very ambiguity of the concept, its schizophrenic tendency to be all things at once, that is a main attraction of ethnicity. But this flexibility comes at the price of theoretical sloppiness. Too many ethnic historians still show strong strands of stereotype and sentimentality, although this is beginning to change.

Recently, ethnic scholars, showing a heightened concern with the nature of their key concept, have sought to clarify how ethnicity works in historical terms. Werner Sollors has criticised the orthodox handling of ethnicity for its static and timeless nature, "isolationist" tendencies, and assumption of original, authentic cultural values. Instead he wishes to see ethnicity as ever-changing, as a manifestation of experience. Like labour history's avant-garde, Sollors has been influenced by post-modernism, particularly its idea of "invention," in which "reality" is a matter of perception generated by a discourse of the individual or group and the surrounding world. Ethnicity "is not a thing but a process," he asserts, "a result of interactions." 25 Again, such relativism has its dangers for historians. By not specifying exactly what drives this "process" or what is interacting, such an approach only begs the question of what is ethnicity. For example, Dale Knobel and David Gerber are among the few historians who set out with a clear definition of the term, both portraying it in ideal terms. Knobel sees it as a social-psychological phenomenon,

${ }^{24}$ By comparison, Donald Akenson estimated that before the Famine immigration, Protestant Irish outnumbered Catholics two to one in Ontario. "Ontario: Whatever Happened to the Irish?", Canadian Papers in Rural History, v. 3, ed. Akenson (Gananoque, Ont.: Langdale Press, 1982), 220-21.

25 Werner Sollors, "Introduction: The Invention of Ethnicity," in the Invention of Ethnicity, ed. Werner Sollors (Oxford: Oxford University Press, 1989), ix-xx [quotations on $\mathrm{xv}, \mathrm{xix}$ ]. 
subjective rather than objective, and a result of collective historical experience. Unfortunately, he does not explain what shaped that historical experience. Rather he is satisfied with what people perceive ethnicity to be, believing thought is the crucible of action. Clearly, how thought was arrived at is of equal or greater importance. Gerber maintains that he does not assume the existence of an ethnic group, but analyzes its formation through a process he terms - in a horrible social-scientific neologism "ethnicization." "The new ethnic groups were formed in America as a consequence of a complex fusion of Old World social forms, cultures, symbols, and psychologies and New World economic, political and social experience."26 Yet he does not explain how the "Old World social forms" were themselves constructed. Ethnicity for him, much as for Knobel, amounts to a consciousness formed through social interaction, but this new ethnic history offers us process without due process, a maximum of model with a minimum of longterm historical documentation. The implications of their argument are not fully thought out and ethnicity, as a result, remains as elusive as ever. To get at its essence one must peel back the obfuscating layers of consciousness and experience to get at the material reality beneath.

Migration and adaptation was a painful experience, one undergirded by a process of class formation. Pushed into wage work by the breakdown of the peasant economy as the opportunity to make a subsistence from the land was slowly stripped away, many found leaving the Old World was their only logical alternative to deprivation. Those that ended up in North America may have had a better life relative to that at home, while their ethnicity proved an important factor in their new lives, giving them a basis of social organization in a potentially destructive environment. But for most it was still a hard existence as their "foreignness" was exploited to drive them into scut work like canal digging. Ethnic groups congregated together, but often in deprived ghettoes characterized by high transience and crime rates. Their experience was thus shaped by class forces, by their virtually powerless position with regard to the means of production.

This interpretation of the immigrant experience depends upon striking a balance between class and ethnicity. Labour and ethnic history have often been at loggerheads over this issue, the two concepts treated as mutually exclusive, or at least ranked in importance. But the conflict is

${ }^{26}$ Dale Knobel, Paddy and the Republic: Ethnicity and Nationalism in Antebellum America (Middletown, Connecticut: Wesleyan University Press, 1986), Preface; Gerber, Making of an American Pluralism, xiv, I 17 . 
more apparent than real, and results from the essentially similar cultural approaches of the two fields. This false impasse can be removed by refocusing the debate. First, it should be accepted that class is primarily an objective condition rooted in the means of production. It puts on a human face necessarily because people are the grist for its mill. Their consciousness of their condition is naturally fitful and intermittent. By comparison, ethnicity is not material but ideal. It has no biological basis, but dwells in the realm of consciousness, making sense of a particular group's shared experience. In this, it is similar to the ideology of class, and it is in this field of consciousness that the class versus ethnicity battle is fought. At the same time, ethnic consciousness can act as a form of class consciousness rather than as its antithesis. If an ethnic group's experience overlaps with its members' experience of class, as initially happened among the Irish, the worker is likely to see his world through Irish eyes. If not consciousness of class in the pure sense, this is hardly false consciousness. But addressing ethnicity only on the ideal level ignores the fact that it was cultured and constricted by material forces. The social and economic relationships thrown up by these forces create a terrain of experience that is given meaning by how people understand and articulate often incomprehensible objective existence. Through an ongoing dialectical process of the material and experiential, an ethnic culture is constructed that, while everchanging, gives the impression of constancy. Its powerful grip on community consciousness endows it with agency, as people order their lives and make choices according to its unspoken precepts. Nonetheless, ethnic culture cannot be separated from its material roots, that is the development of industrial capitalism in the modern era.

IV

Talking about consciousness is always difficult given history's fundamentally positivist nature, no more so than when addressing groups that left few records of their thoughts, motivations or aspirations. Building models of human agency on such idealistic foundations proves unsound. It is thus somewhat ironic that working-class and ethnic studies are pulled in this direction. Of course, sympathy with the masses makes one wish to portray them in the most optimistic fashion, as independent, sentient, active and conscious members of autonomous and politicized collectivities. There is obviously much to be said for this rendering of their experience, but it is not the sum of their existence and perhaps not even the best way to read their lives. Working people were largely powerless in the face of 
broad material forces that sought to shift them from place to place and strip them of resources. Their relative absence from the historical record is a measure of this weakness. With little control over their fate, historically mute, workers of whatever ethnic group were agents of the devil, driven by the needs of industrial capitalism. The love of labour thus needs to be tempered with hate of their condition.

In light of these observations, how are we to reconstruct the Clark's Ferry strike of 1828 ? With the limited sources at hand, it is only possible to sketch the episode; pretensions to an understanding of the workers' consciousness must be avoided. First, these were Irish labourers, many likely recent immigrants who had fled a country in the throes of economic collapse. Their traditional culture had been eroding for the past century, and most had been peasants only in name. Rather than some innate sense of Irishness, they imported with them a burgeoning tradition of collective violence forged in the battles with Irish landlords and English imperialists. If anything, it was this group experience with exploitation and class struggle, not some idealized ethnic consciousness, that informed their actions. Second, these labourers were not the bowed but unbroken craftsmen of much working-class history. They were not infused with a republican sense of injustice done or regret for a failing commonwealth, but apparently more concerned with eating and mere survival. Thus, after a winter of discontent they lashed out, not to solidify ethnic community or advance labour's cause, just to pay their debts and put more food in their bellies. Willing to commit violence, attack their mates, and fight local authorities to achieve these ends, they were also meekly led back to the fold by the intercession of their spiritual shepherd. Pushed and prodded by forces beyond their control or ken, with their material needs first and foremost in their minds, these Irish labourers - like the bulk of working people - were humans not heroes, subjects more than agents. 